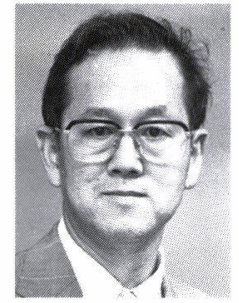

\title{
皮膚のバリア，角層をめぐる咨症
}

\author{
田上八 朗*
}

\section{special lecture}

\section{JAPANESE JOURNAL OF INFLAMMATION}

京極先生，過分なご紹介いただきましてありが とうございます.

この炎症学会では私が東北大学に来てまだ 2 年 目，京極先生が会長をされましたときに，乾癬の 炎症に関して特別講演の機会を与えていただきま した，それから 14 年がたち, 今度はもう少し巾広 く話をさせていただきたいと思います。

皆様の皮膚の表面には角層があるのですが, だ れもこの角層の存在は気がつきません.せいぜい, そのかけらが皮膚の表面からフケなどで落ちると きに気がつくぐらいです，日に焼けたりすると 1 枚のペラッとした膜がむけてくるので，体の表面 に垢の膜があるということに気がつきます。

病理組織で正常の角層というとスケスケな構造 でしかなく，まず表皮に目がゆきます。けれども， 実は表皮の存在の意義はこの角層をつくるために あります。これがないと私たちは地上では生きて ゆけません。

角層は表皮を構成する細胞，ケラチノサイトが 約 1 カ月かけてゆっくりと死骸になって積み重 なった構造で，約 2 週間で体の表面から垢として 毎日一層がむけ落ちています。ですから表皮から 角層までだいたい 1.5 力月ぐらいの非常にゆっく りした turnover をしてます。ところが少しでも皮 膚が刺激を受けると,この過程が短くなり，ひど い皮膚炎では数日となりますから，機能のいいか げんな角層ができてきます。

そして炎症ということから重要な点は，ふつう は自分のものではないとして攻撃の対象になる組 織はわれわれの体の中にないのですが，角層だけ

\footnotetext{
* 東北大学大学院 医学系研究科 内科病態学 皮膚科学分野
}

は体の外側につくられ捨てられている組織ですか ら，異物として認識されます。これはわれわれに とっては, ある意味では外敵に対し速やかに炎症 反応を起こすために非常に大切な働きでもあるわ けです。角層が傷つくことは炎症の一番最初の引 き金を引きます。

\section{角層の機能}

角層は厚さ $10 \sim 20 \mu \mathrm{m}$ のポリエチレンのラッ プぐらいの薄い膜状構造物です。一番メインの働 きは水の岥失を防ぐことです，体の中に $70 \%$ の水 がないと,われわれは生命活動を行えませんので, そのためのバリア膜です。逆にいうと水もほとん ど通さないから，ウイルスであろうと大きな分子 であろうと角層に傷がない限り体の中へ入らない わけです2).

本当の角層の姿は非常に緊密な組織で, 凍結切 片で見ると板のような平らな角層細胞がだいたい 14〜15 層積み重なって, がっちりとお互いが結び 合っています(図 1)。この無構造な角層細胞一つ ひとつの蛋白の固まりの間をセラミドに富み, ラ メラ構造をした脂質が満たしています。ですから 体内の水分がここを通り抜けてくるなどというこ とはなかなかできないし，われわれの体の外から もだいたい分子量 500 以上のものは通過できませ ん、ただし炎症のあるようなところで，にわかに つくられた角層は，バリアの機能が悪いため外用 剂を塗っても,よく吸収されて効くわけです、治っ てしまった皮膚に塗ってもあまり入ってゆきませ ん.

角層細胞の間のラメラ構造をした脂質は表皮の 一番上層の顆粒細胞の層板顆粒の内容物が放出さ 


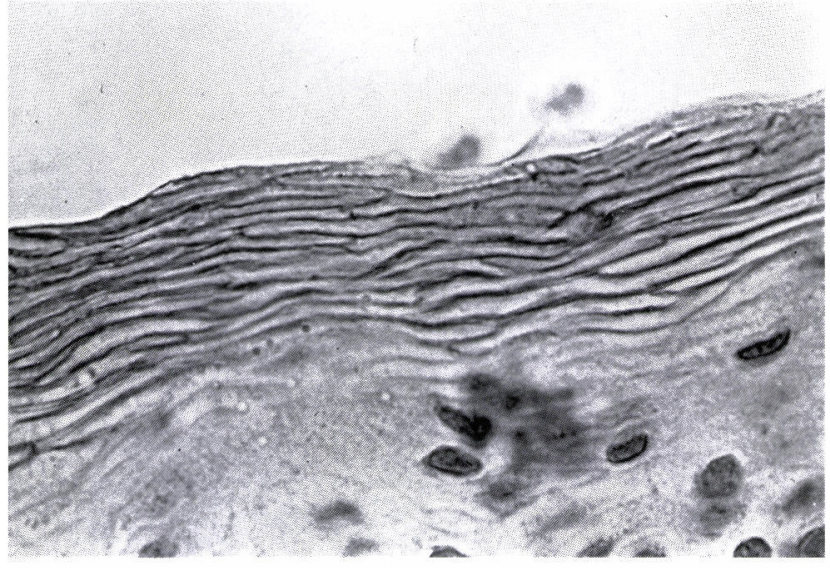

図1 凍結切片に 10\%苛性力リ水溶液を滴下し, 膨潤した角層の組織像

れ，この角層細胞の間を全部満たしたものです。 この角層を生きたままで機能がどうであるかと いうことを調べるために使われる方法は皮膚の表 面加表皮を介して角層をわずかに通り抜けてく る水蒸気の量を計る方法です。

気温 $20^{\circ} \mathrm{C} く$ らいで汗をかかない状態で表皮, 角 層を介して抜けてくる水の量を計ると, 正常な皮 膚ではほんのわずかです。こうして，角層のバリ ア機能，ものを通さない機能がはかれます。これ を経表皮水分喪失 transepidermal water loss (TEWL) と呼んでいます。

粘着性のセロファンテープをはりつけ，はがす ことによるストリッピングを 20 回ほどしながら 皮膚の表面から角層を取り除いていくと, TEWL は次第に上昇し，最終的に角層がすべて除去され ると水面からと同じ水の蒸散の状態になります。 たとえばアトピー性皮膚炎などの病変部の皮膚は 一見すると厚く力业少していますが，実はここ から水がたくさん抜け出ています。正常皮膚のよ うに見える非病変部からも水がごくわずか通り抜 けてきます。このように正常のゆっくりした角化 の状態にくらべ, 炎症のある皮膚でのように 1 週 間, 10 日というような形で短期間にいいかげんな 機能しかもたない角層がつくられると, もちろん バリアの機能も悪いことは当然です.

もう一つの角層の大切な働きとして，しなやか でなめらかな皮膚を保つことが挙げられます。だ
れでも梅雨時には角層の中に水が十分蓄えられて 非常にやわらかな皮䖉です。それが冬になると皮 膚が力サカサになります。お年を取られるとさら に角層の水がなくなって冬はカサカサになって, しかもひび割れして, かゆくもなります。老人性 搔痒症といいます。

角層は水がないと固くなるということは試験管 内の測定ではわかっていましたけれど，皮膚に電 極を当てて一瞬にして水分量を計る方法を，いま から 20 年前に私たちは開発しました。それは高周 波の伝導度, あるいは電気容量, 要するにインピ ーダンスをはかる方法です。電極を当てると一瞬 にして角層の表面の水分含有量がわかります。

この器械でストリッピングをしながら皮膚の表 面から中に入りつつ調べると,たつた $10 \mu \mathrm{m}$ とい う薄い角層内に，湿った表皮と接する部分から乾 いた表層までの水分の濃度勾配がみつかります。 当然，皮膚炎のある皮膚で急造された機能的に劣 る角層は水を保つことができないために白っぽく 見えます。頭のフケも白っぼく見えますが，同じ 水を保てない角層です。ですから病的な皮膚では バリア機能と水分の保持機能は, ある程度相関し た関係があります。

実際には角層にある水溶性の低分子のアミノ酸 含有量 (天然保湿因子) 臨床的な皮膚の乾燥の度 合いとかなり比例します。そういうものが溶け出 さないように，またそれ自身も水を保つように細 胞間を充たしている，もちろんバリアに重要な角 層の細胞間脂質も，角層の水分保持に大きな意味 をもちます。ですから角層はちょうど風船のよう にわれわれの体の中の水が失われるのをつなぎと めて皮膚の表面に水分を保持してやわらかさを， 一方バリアとしてものを通さないという働きをし ています。今までのことを実は 3 力月前に私は中 公新書で「皮膚の医学」という本に書きました22. もし興味がおありでしたら角層の機能のことをや さしく書いたつもりですので，お読みいただけた らと思います。

\section{角層が起こす炎症による皮䖉疾患}

さてこの炎症学会での今日のメインの話は，角 
層自身がわれわれの組織液の補体に接すると，す ぐにそれを活性化して炎症反応を起こすという話 をさせていただきます。

爪も角層です。このごろは非常にきつい靴をは く方では足の親指の爪がつよく弯曲して陥入爪 (ingrown nail)を生じ，炎症を起こして来ます。 このように角層が皮膚組織に入ると非常に激しい 炎症を起こします。あるいは，まれな疾患で穿掘 性毛囊炎(dissecting cellulitis) という慢性膿皮症 では，実際には細菌感染はあまり関係なくて頭の 皮膚に毛が刺さることが原因で非常に激しい炎症 を起こします。おしりの周りの毛が刺さって起き る毛巣瘻 (pilonidal cyst) や毛が曲がっている人, とくに黒人の男性がヒゲを剃刀でそると，毛が刺 さってよくあごの下に肉芽腫が出きてきます。こ ういうふうに毛が刺さることによって䰅䯻部偽毛 囊炎 (pseudofolliculitis of beard) という炎症が起 きます。

脇の下の化膿性汗腺炎 (hidroadenitis suppurativa）はアポクリン腺の炎症といいますけれど も，実際にはアポクリン腺が開口する毛穴の中に 角層が詰まって破裂する状態が起きます。そうす ると非常に激しい炎症が起きます。

たぶん皆さんも多かれ少なかれ必ずかかったこ とがある，いわゆるニキビ，痤瘡では，毛穴の中 に角層が詰まって，それが外へ出ないで破裂する ために炎症を起こします。これは皮脂がたくさん 出る年頃になると，だれにも起きます。

ステロイドを痤瘡の治療に使うと, はじめは確 かに炎症を抑えるのですが，実はステロイドは角 層をますます毛穴の中に残りやすくして, 結局ひ ぞい，お互いがトンネルをつくり交通するような ステロイド痤瘡も起こしえます。

(図 2)

\section{角層の起炎作用}

角層片を実験的に生体の皮膚の中に入れると， 24 時間でこの周りに好中球がいっぱい集まって きて角層を壊してゆこうとします。私たちの体で つくられる組織で，こういうことを起こすものは 他にはありません。つまりわれわれの皮膚の表面 には薄い異物が覆っていると考えいただいたら良

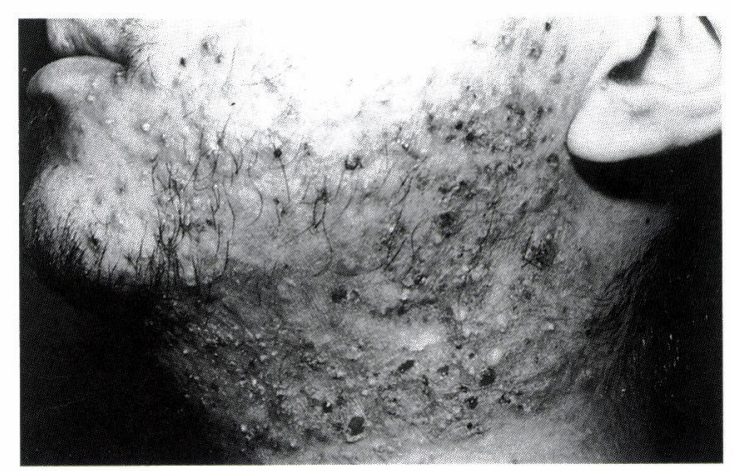

図 2 ステロイド痤瘡の臨床像

いかと思います。

私たちの教室の照井正講師と大学院生の小沢麻 紀さんがやった実験では, ふつうの角層, あるい は爪，毛などを何も処理しない正常血清と混ぜる と, そこに強い白血球遊走活性が出てきます。実 際には補体の活性化の結果そこに生じてきたC 5 a アナフィラトキシンが白血球を引き寄せるわけ です3)，この補体の活性化壮試験管内で，角層を EGTA でキレートしカルシウムのないマグネシ ウムイオンだけある血清と, あるいは無処理の血 清と混ぜて調べてみますと, どちらでも起こりま 寸(図 3)，そして alternative pathway 活性化の場 合にはファクターB が $\mathrm{Bb}$ に変換します。

in vitroの状態で角層片を, カルシウムをキ レートしマグネシウムイオンだけ存在する血清と 混ぜても，ふつうの血清と混ぜても，同じょうに Bbができますし，C 5 a アナフィラトキシンも同 じようにつくられます。ということで, 角層は異 物と同じように，補体の alternative pathwayを 活性化します。われわれの皮膚の表面には異物が ある、というふうに考えられます4).

皮膚からはがした角層に血清をかけて，それを 洗って，そこに白血球をふりかけると白血球は角 層に接着します.白血球の $\mathrm{Mac}^{-1}$, つまり CD11b, それからCD 18 が角層上の補体のC 3 bi にくつつ くためです5). $\mathrm{Mac}^{-1}$ に対するそれぞれの抗体で 処理すると, 白血球はくつつかなくなります。つ まり白血球はこういう血清処理し, オプソナイズ した角層の上に補体を介して接着するようになり ます。角層をモルモットの皮内に埋め込んだ実験 


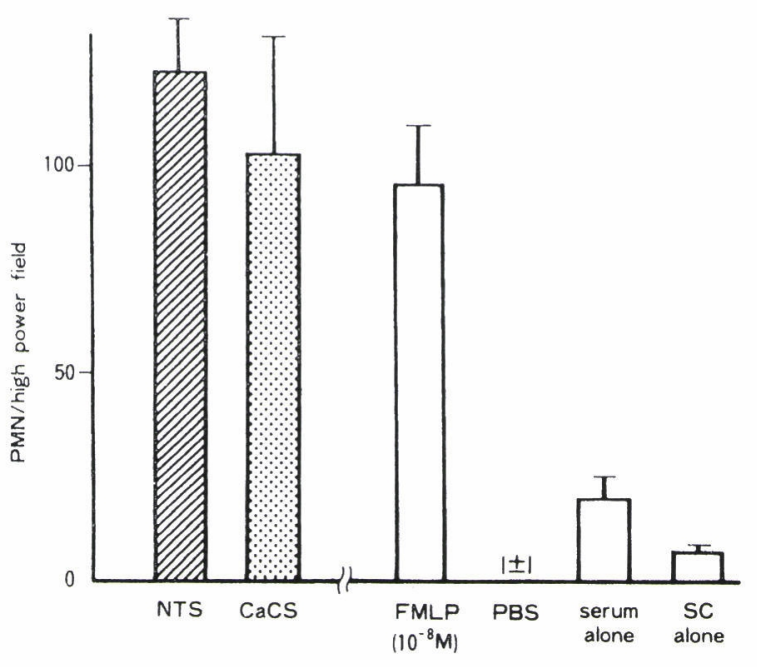

図 3 角層と血清との反応による白血球走化 活性の産生

角層片とカルシウムをキレートしマグネシウムの み存在する血清 $(\mathrm{CaCS})$ とを反応させると生じる 白血球走化活性は，何の処理もしない正常血清 (NTS) と反応させた場合とほとんど変わりがな い. FMLP は走化活性をもつ陽性対照であり，リ ン酸緩衝生理食塩水(PBS), 血清だけ, 角層 $(\mathrm{SC})$ だけではほとんど活性はない。(文献)より引用)

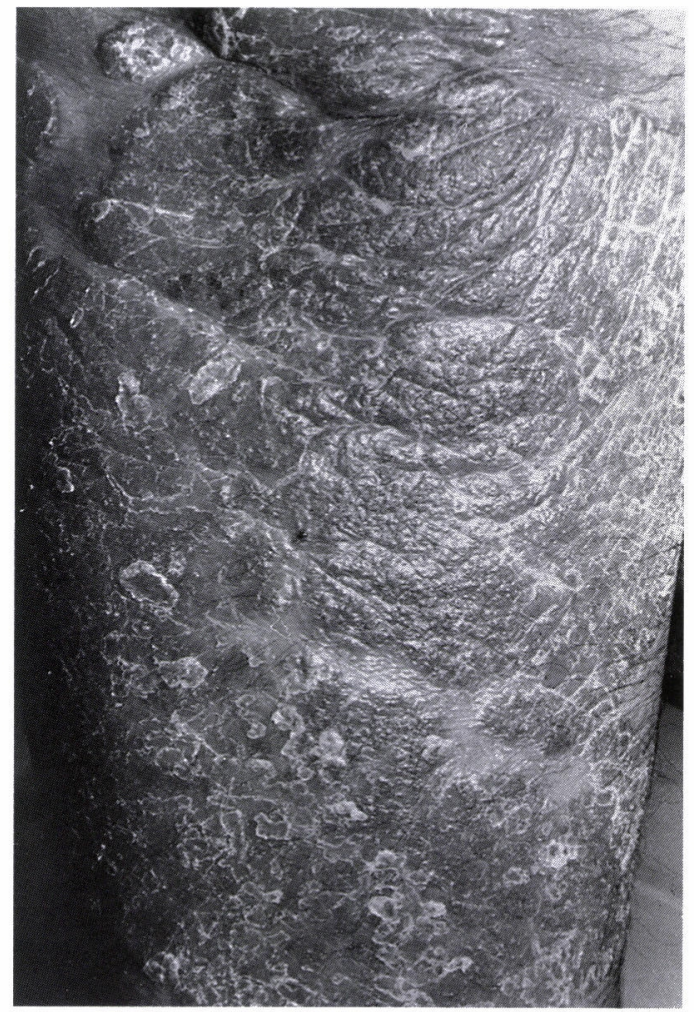

図 4 乾癬の皮疹の臨床像

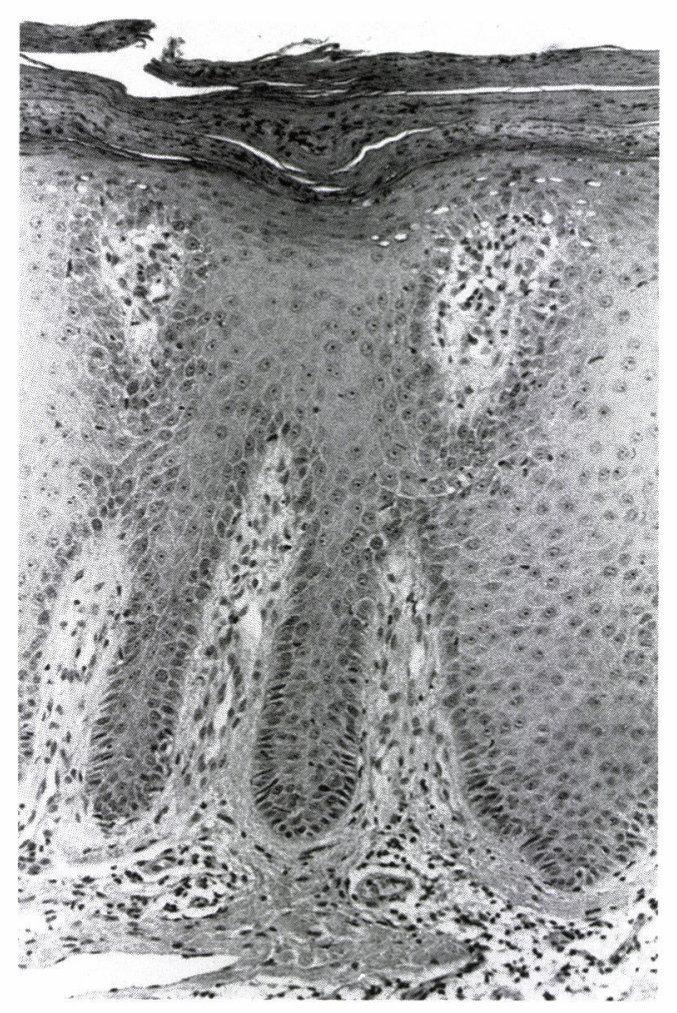

図 5 乾癄病変部の病理組織像

表皮突起の延長と厚い角層内には好中球の遊 走した残骹である Munro 微細膿瘍を認める ほか, 真皮の血管周井には, リンパ球の浸潤 を見る。 
で，4 日目では，白血球もありますが，その周りに はマクロファージ， あるいは巨細胞が出現し，い かにも異物反応の様相を呈します。毛でも爪でも 同じことが起きます。先ほどの小沢，照井たちの 実験で，白血球と血清処理しオプソナイズした角 層と結び合わせておいて，単球に対する走化活性 がでるか調べると, 接着した好中球がある程度単 球を引つぱる走化性因子を出します3).

こういうことで，ひとたび正常の角層でも私た ちの体の中に入れば激しい炎症を起こします。

\section{角層下に無菌性膿疱をつくる皮膚疾患群}

この角層を中心とした炎症の起きる病気で乾㾕 があります。白人ではだいたい 50 人に 1 人くら い，日本人ではそれよりも 1 けた少ないぐらいの 病気で，中年からはじまります。このような赤い 斑の上に角層の鱗屑がいっぱいたまった変化が出 てきます(図4)。

この病気では表皮が非常に増殖してきますの で，かつては表皮の異常な増殖と角化の異常の病 気というふうに理解されていました。しかしこの 病気にシクロスポリンが特効的に効く, しかもシ クロスポリンは表皮の増殖を抑えないような濃度 でも効くとか，あるいは実際には T 細胞に対する モノクローナル抗体, 抗 CD 3 あるいは抗 CD 4 モ ノクローナル抗体で治療すると, 投与されている 間は,この病変が治ってしまうということで, T 細胞を介する疾患であることがわかりました6).

ごらんになると抒かりのように，真皮には CD 4 T 細胞を中心とした浸潤が，角層の中には このような白血球の死骸が見られます. Munroの 微細膿瘍といいます(図 5).

炎症が激しくなると肉眼的にも膿疮が見えま

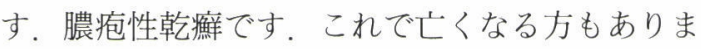
す。こういうときには角層の下には海綿状の膿疱 が形成され，たくさんの白血球の集積があります (図6).

ですから乾癬は基本的には炎症性の疾患であっ て,しかも Tリンパ球を中心として起きてくる病 気ですが，ユニークなことは，角層の下にこのよ うな膿瘍をつくりやすいということです。

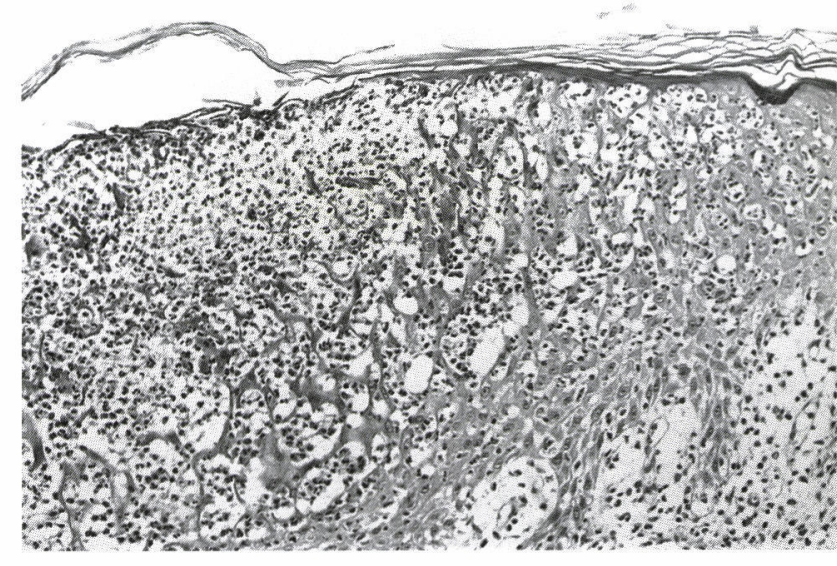

図 6 膿疮性乾㿍の組織像

角層下に白血球多数いれた Kogoj 海綿状膿疱 形成をみる。

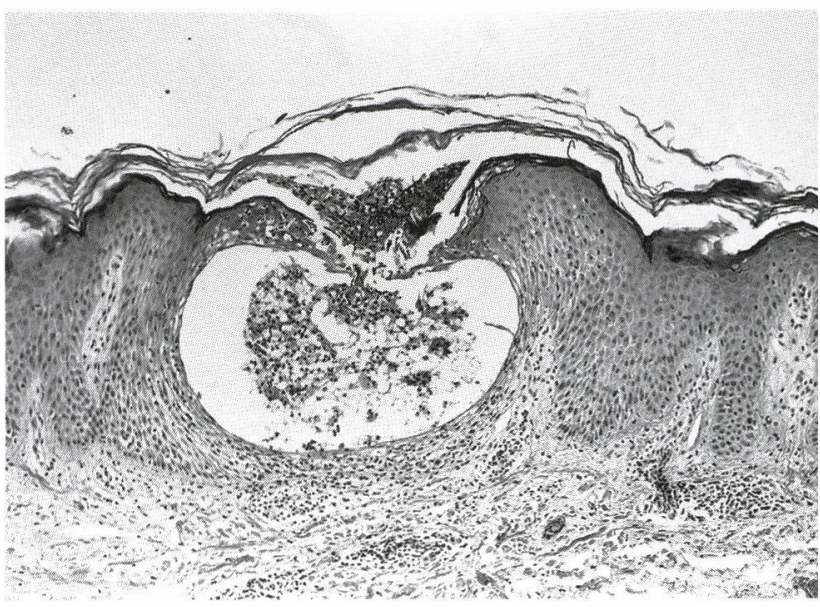

図 7 掌蹠膿疱症の組織像

角層下の単房性の膿疱形成。角層に張り付くよう に白血球の集積がみられる

あるいは角層下膿疱症という類症があります。 これなどは乾癬のような病変はないけれども, 膿 疱だけが出てきます。いわゆる子供の黄色ブドウ 状球菌による膿痂疹(トビヒ)にそっくりです。

さらに乾癬の類症といえるようなものでは，掌 蹠膿疱症 (pustulosis palmaris et plantaris) とい う病気があります。手のひら, 足の裏に慢性の膿 疱, 実際には菌がいない無菌性の膿疮ができます。 そして半数以上の人では扁桃などの慢性の感染病 巣を治療すると治ってしまいます。ですから，そ れが引金を引いてこういう反応を起こしていると 
思われます。この組織像も膿疮が角層下にあって, 白血球は角層に接着し，それをかき落としている ように，あるいははげた角層片のまわりにロゼッ トをつくっています(図7)。こういう人で急に扁 桃が痛くなって, 上気道感染があったりすると, 全身に関節痛が出たり, 多数の膿疮が出てきたり もします。

一般的な湿疹性病変，たとえばアレルギー性接 触皮膚炎でも激しく起きると膿疱ができることが あります。ですから別に乾痽やその類症だけで白 血球があのように集まるわけではなくて, 正常の 人でもこういう膿疱をつくることはあります。特 に金属の接触皮膚炎ではそういう傾向がみられま す.

白血球が角層下に集まってくるような病気でド イツの von den Driesch が白血球の細胞膜に何の レセプターが発現しているかを調べたところ,

CD 18 と CD 11 b, 先ほどいいました白血球が血 清処理した角層にくつついたと同じょうなレセプ ターMac-1がほとんどのものに見つかる，という ことを認めています7).

\section{乾㿏病変の炎症の発症機序}

乾拜の炎症のある病変部から, 凍結切片をつ くって白血球をふりかけてみます。そうすると白 血球が張りつく部分があります(図 8)。ふつうの 皮膚の角層にはくつつかないのです。白血球が くっつくのは全部病変部のC 3 の沈着した角層の ところです。しかもくっついた白血球は, NBTを 一緒に与えると, それを領食し活性酸素を出し, 酸化し黑色の formazanの結晶が細胞質にみられ ます。つまり乾痽の病変部には白血球の粘着性を まし，それを活性化する物質があります ${ }^{8)}$.

先ほど京極先生がご紹介くださいましたよう に, 今から二十数年前にこういう現象を起こすた め, 何か乾癬の鱗屑の中に特別な物質があるので はないかということで鱗屑をたくさん集めて，す りつぶして, 当時は市販のものがありませんので, 自分でボイデンチェンバーをつくり白血球走化活 性を調べました。ボイデンチェンバーの下室に鱗 屑の抽出液を入れ, 上室に白血球を入れ, そして
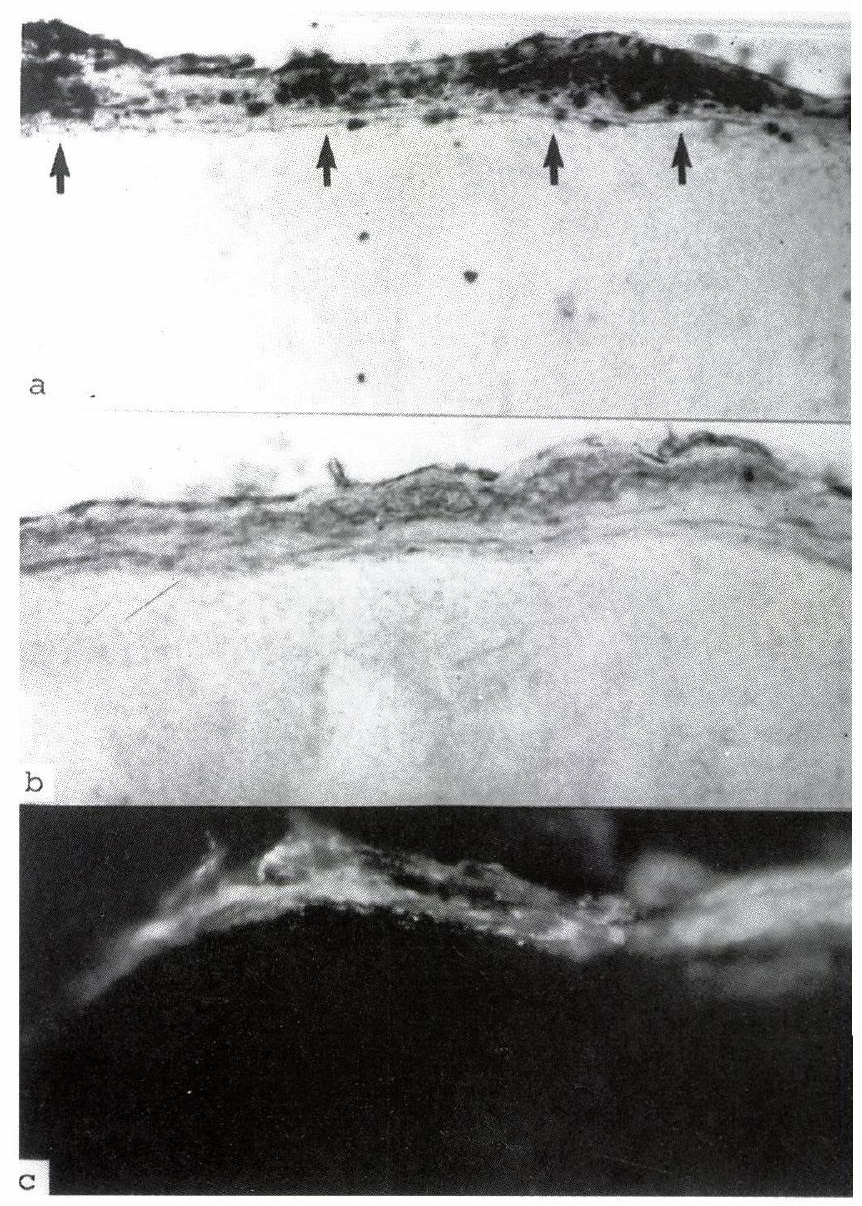

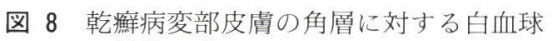
の付着反応

凍結切片に白血球晒濁液をかけると, 白血球はそ の角層に接着し, 加えたNBT を貪食し, 活性酸素 産生により黒いformazan を形成する(a). 対照 でNBT 液のみ反応させても，ほとんど角層に変 化はない(b).このような角層には C 3 の沈着が認 められる (c)。(文献 ${ }^{8)} り 引$ 引)

$3 \mu$ 小孔をもつミリポアフィルターを介して引つ ぱられる白血球の数を数えてみました。

結果として分子量だいたい 1 万前後の分画に高 い走化活性が見つかり psoriatic leukotactic factor (PLF) と名づけました.

これをモルモットの皮膚に注射すると，血液の 中のエバンスブルーがそこの部分に漏れてくる (図 9).つまり白血球を引つぱる力のほかに, 血管 を拡張し透過性を増す働きがあります。当時は補 体のC 5 aアナフィラトキシンが知られていまし たので，乾癬の鱗首の中には C 5 a があるだろう 


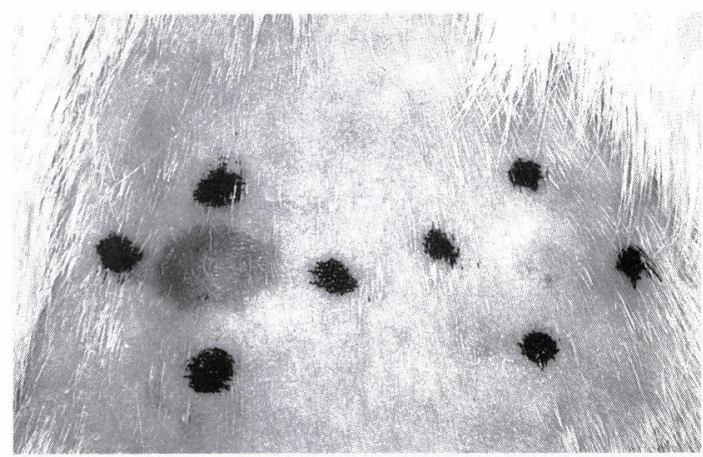

図 9 Psoriatic leukotactic factor 含屯乾 癬の鱗屑の皮内注射部位.

血管内のエバンス・ブルーが血管壁透過性の亢進 により, 数分後から漏出してくる

と考え, 実際に抗アナフィラトキシン血清を使つ て確かめることもできました。この病変部角層の 中に含まれる補体成分の中には, classical pathwayで出るC 4 の切れ端に比べ, より多量の alternative pathway 活性化による Bbが必ず見 つかります。ということで, その主体は角層と血 清との反応が補体の傍経路を活性化し, 白血球走 化性活性をつくり出しているのだろうと考えまし た。

この psoriatic leukotactic factor と, これに対 する抗血清, 抗アイタイアナフィラトキシン血清, それから PLF自身で沈降反応をさせますと，ア ナフィラトキシン以外の物質もたくさん存在する ことがわかりましたが，それらの本態が何である かずっと不明でした。

抗 C 5 a アナフィラトキシン血清はザイモザン で活性化した血清では，その活性をほとんど抑え てしまうのに, 乾癬の角層の中の白血球遊走活性 の全部は抑えません。乾癬, あるいは掌蹠膿疮症 などのいろんな膿疱性疾患の鱗屑抽出液の同じ分 画の活性をかなり抑えますが, 少なくともそれ以 外のペプタイドの存在が確認されました(図 10） ${ }^{10)}$. これが何かわからなかったのですが，ドイ ツの研究者たちが, anionic neutrophil activating peptide, ANAP という名前で報告しました ${ }^{11)}$ ，そ の時期にはじめてケモカインの存在がわかってき て, 結局これはIL-8であるということが同定さ れました。つまり乾袢の鱗屑の中には IL-8, 実際

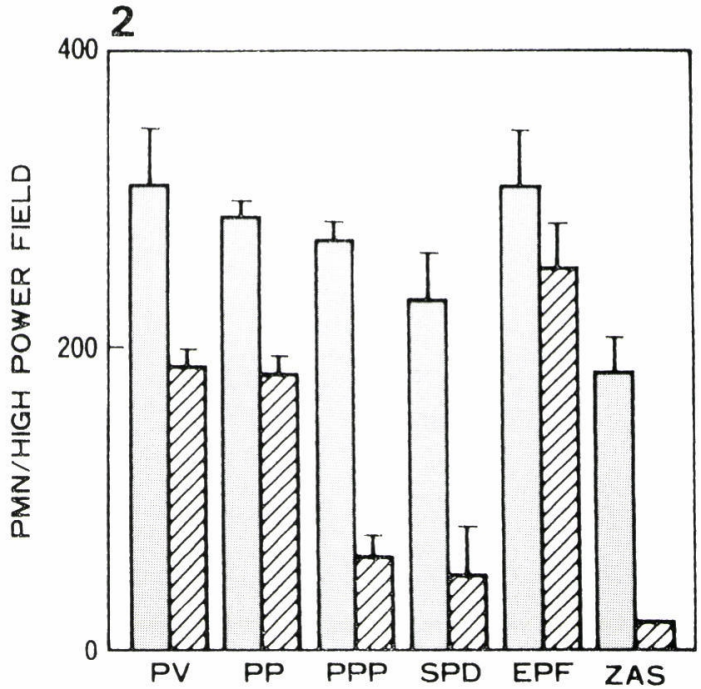

図 10 抗 C 5 a 血清による角層下膿疱を形成す る疾患の病変部の鱗屑抽出液のPLF を 含む分画の白血球走化活性抑制効果の比 較. PV は尋常性乾癬, PP は膿疮性乾㿏, PPP は掌蹠膿疮症, SPD は角層下膿疮 症, EPF は好酸球性膿疮性毛囊炎, ZAS はzaymosanで補体を活性化した正常血

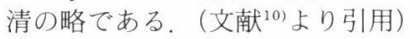

には Gro- $\alpha$ やその他のサイトカインも存在しま すし, C 5 aアナフィラトキシンも存在します6).

IL-8 は乾癬で確かに表皮内にも非常に大量もつ くられますが，ほかの炎症でも出てきます。たと えば先ほどのストリッピングをして引つかいた皮 膚でも表皮細胞は IL-8をつくりだします。非特 異的な刺激, 乾燥あるいは洗剤の sodium lauryl sulfateの刺激でもケラチノサイトは IL-8 をつく るし，そのほか血管内皮細胞，あるいは線維芽細 胞も IL-8をつくります。ということで,いろんな 慢性の炎症で，ましてや乾撚の病変で皮膚の構成 成分は IL-8をつくります。

乾癬の鱗㞕の中の白血球遊走活性と, これらの 成分との関係を調べてみました ${ }^{12)}$. IL-8 は鱗首の 中に必ず見つかります。一方補体のC 5 aアナ フィラトキシンは非常にばらつきがあり, 見つか らない例もあります。白血球走化活性と走化因子 との関係では, C 5 a との間には有意差が認められ ました. IL-8 と補体成分との間にも関係が見つか るかと思ったのですが, 見つかりませんでした(図 

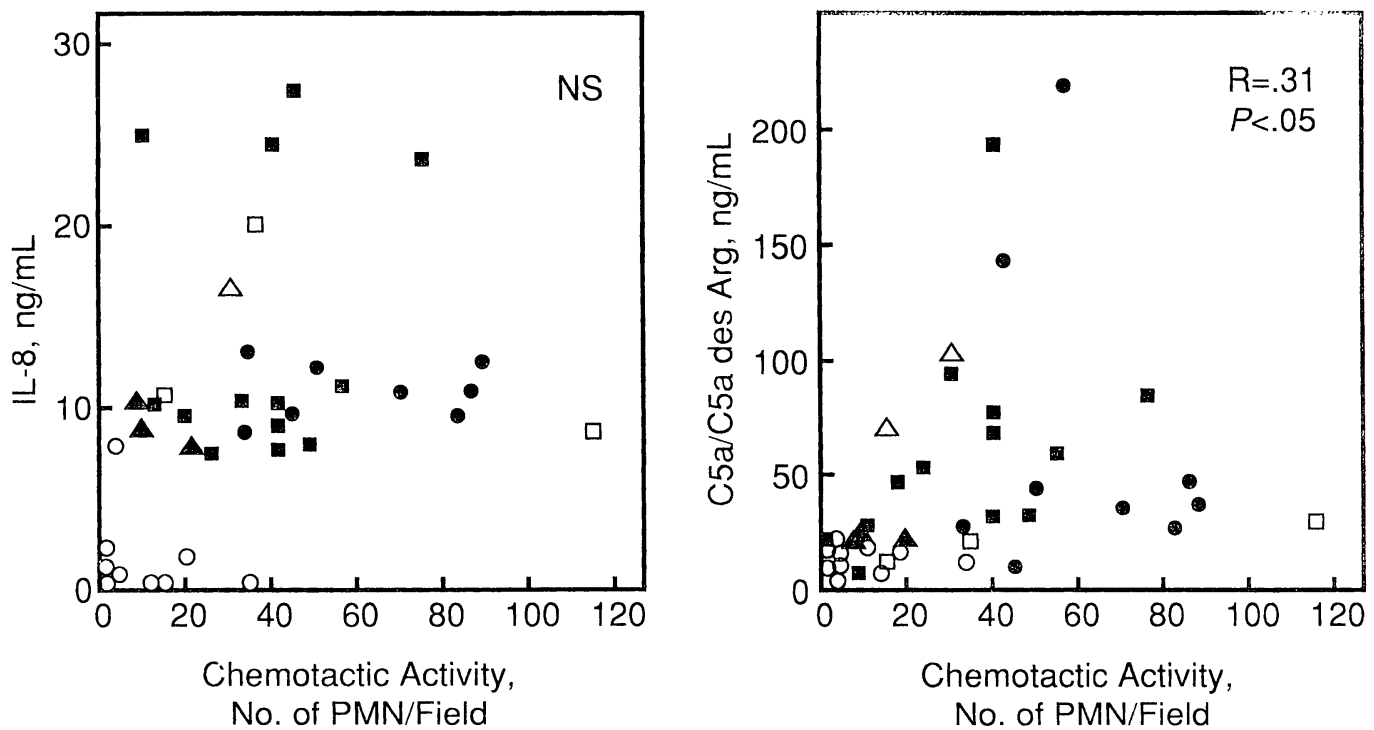

図 11 乾癬ならびに類症の病変部鱗首抽出液し白血球走化活性と IL-8 と C 5 a の含有量 との相関。は正常角層, ○は尋常性乾癬, 口は膿疮性乾癬, 口は紅皮症性乾癬,

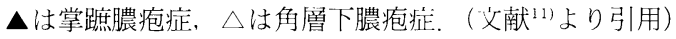

11)、ノルウェーの研究者たちも，ザイモザンなど 同じ重量のもので血清を活性化するよりも乾癬の 鱗屑ではずっと大量のC 5 a があるという論文を 1992 年に発表しています13). ですからC 5 a の存 在は非常にユニークです. 乾癬の病変部で, C 3 の 存在を調べると, やはりこの部分にC 3 がいっぱ い沈着しているのがわかります(図 $8 \mathbf{c}$ )。

その元地は何か、乾癬の病変部では全体に白血 球の遊走があるかというと，そんなことはないの です。むしろ多くの部分では慢性の皮膚炎の像か らなり，表皮が増殖してリンパ球が浸潤するとい う像をとっています。教科書的な乾摩の病理組織 というのは全般的には見つかりません。むしろ慢 性の炎症のところどころに白血球の遊走のある部 分があります(図 12)。ですから部分ぶぶんで非常 に滲出反応があるけれども, 基本はやはり Tリン パ球を中心とする慢性皮膚炎であって IL-8 はそ の発症にかかわり，そこにC 5 a ができる状況が 起きると白血球の反応が起きる病気で, 激しく白 血球の反応が起きると肉眼的にも見えるような膿 疱性乾癬となります。

実際には先ほどのシクロスポリンその他の免疫
抑制剂の効果から，乾癬に関する免疫の背景が非 常にはっきりし，いろいろなサイトカインと表皮 のケラチノサイトとの間でのインターアクション があって，そして乾癬特有のあの変化が出てくる ということがわかりました ${ }^{14)}$ SCID マウスに, 乾 癬の患者さんの正常皮膚を移植して，そこに乾癬 の患者さんのリンパ球をスーパー抗原で刺激して 注射すると，実験的に乾癬様の病変をつくれる. ところが, 正常人の皮膚を SCID マウスに植えて, 正常人のリンパ球で刺激しても，せいぜい慢性の 皮膚炎しかできないという実験結果を，アメリカ の Nickoloff たちが発表しました15).

ですから，乾癬の患者さんたちではリンパ球が もちろん異常であり，それと反応しうる皮膚の元 地というものがある。その両者のインターアク ションがあって, 特有の炎症が非常に強く起き, IL-8 などがつくられて，T細胞が表皮内に侵入 し,さらにその反応が非常に強いと, 表皮の上の ほうの角層を覆っている部分まで壊されて，今度 は補体の活性化が起き, 白血球の遊走がはじまり 膿疮が出てくる，というふうに考えています(図 12). 


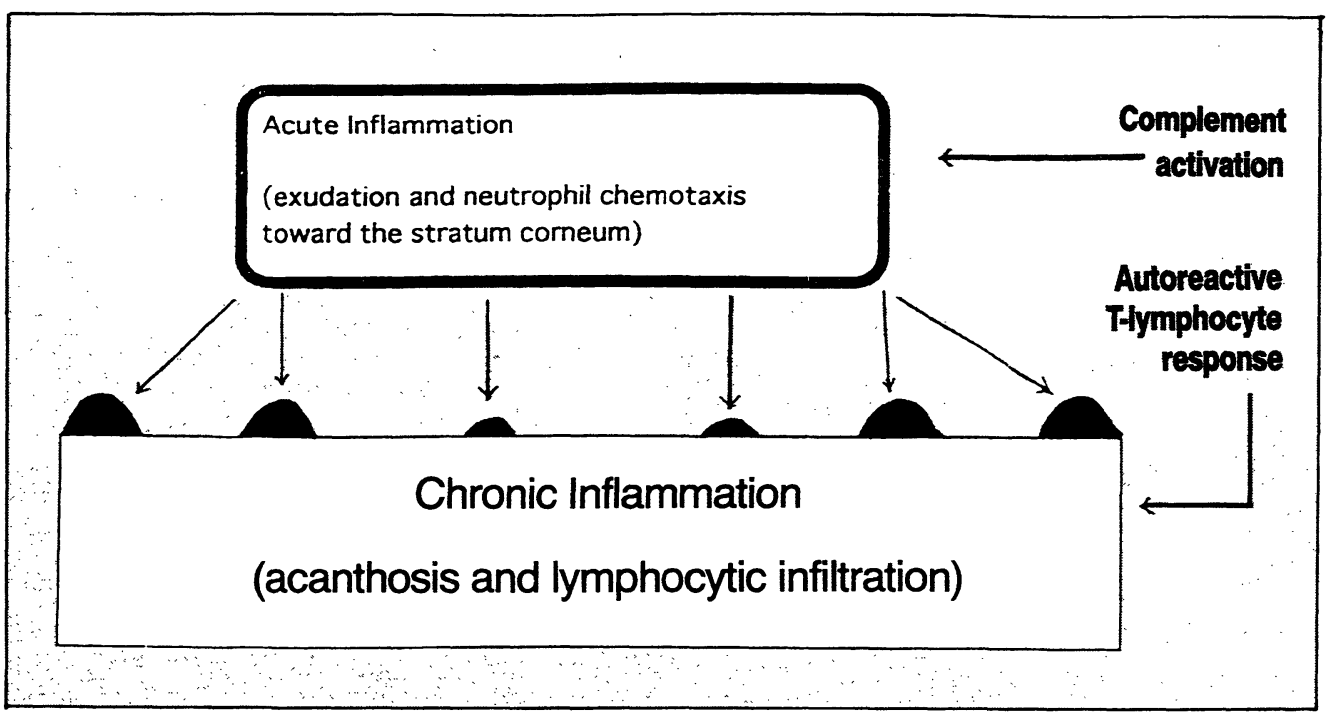

図 12 乾癬病変部における炎症発現機序. (International Dermatology News Vol 27, No 5, p2 より引用)

炎症を起こしうるサイトカインは，実際には表 皮のケラチノサイトがいろいろつくるわけです が，補体係の中心をなす C 3 もケラチノサイトが 産生します。これは私たちの教室の照井講師の データです.ケラチノサイトを培養すると, C 3 は ある程度 constitutively にも少しずつケラチノサ イトからつくられます。しかし TNF $\alpha$ ，あるいは $\gamma$ インターフェロンなどの存在下でのケラチ， サイトは大量のC 3 をつくるようになります(図

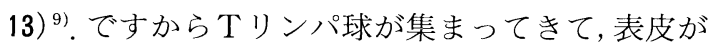
慢性の炎症を起こした場合, これらのサイトカイ ンが表皮細胞を刺激して，補体のC 3 をたくさん つくって，角層が露出すればすぐに補体の活性化 が非常に起こりやすくなるという状況をつくって います。

乾㿏の発症機序はまだ最終的に決着がついてい ません。ではTリンパ球を刺激する抗原となるも のは一体何かということもわかっていません。

乾瘭の患者がよくのどが痛くなった後にたくさ んの皮疹を出すようなことから， $\beta$ 溶血性連鎖球 菌の抗原が何かしているのではないかということ で，いろいろ調べられ，そういう菌由来の抗原物 質とケラチンとの間に交差性が見つかり，それが 何か自己免疫的反応を起こすのではないかという

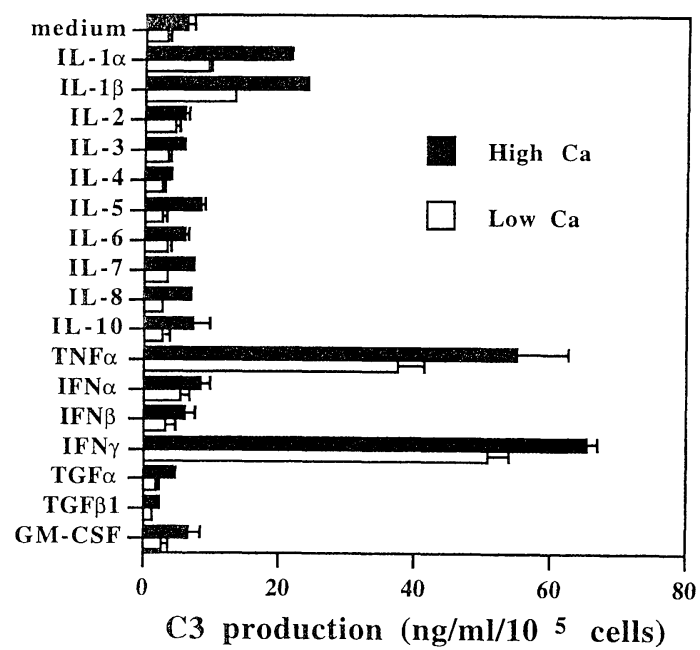

図 13 培養ケラチノサイトからのC 3 産生 に対する種々のサイトカインの影響

High Ca は培養液のカルシウム濃度を $1.2 \mathrm{mM}$ にして細胞の分化促進を図った状態, low Ca はカ ルシュウム濃度を $0.15 \mathrm{mM}$ に低くし, 細胞の増 殖を図った状態での C 3 産生量を示す.

スペキュレーションをしている人もいます16)。は たしてどういうものかは最終的にはまだわかって いません，私たちもこの菌のスーパー抗原に対す る特異的な anergy を患者末梢血リンパ球に認め ています17). 


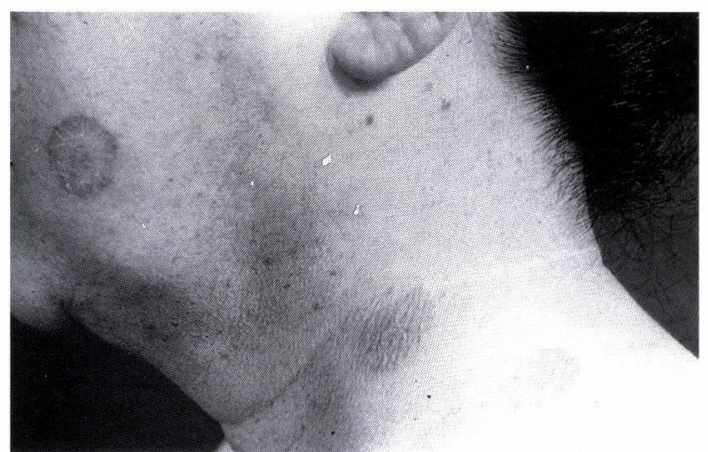

図 14 Microsponum canis による体部白癬 (文献 ${ }^{2)}$ より引用)

乾癬は皮膚の病気だけではなくて，関節も侵さ れる病気です。ですから単に皮膚の成分だけでは なくて，リウマチのような関節炎も起こすため, 関節由来の物質も抗原に十分になりうるもので 寸

\section{表在性真菌症にみられる炎症}

さて，ここにお示ししたのは乾癬ではなくて， 組織学的にそっくりですけれども，いわゆる昔で いうたむし，白癖です(図 14)，角層にかびが生え る, つまり白癬菌が繁殖すると, 炎症を引き起こ して，このような環状になって菌がそこから周辺 に逃げると，炎症がまた追いかける，というかた ちで輪になって広がります。臨床的にも，ときに 膿疮性乾痒に似た病変をつくります。

この場合は白癬菌が角層の中にいまして，ここ へ向かって白血球が遊走します, 当然, 白癬菌が 出寸成分がケラチノサイトを刺激して, IL-8 など も出しますし，そういうことでTリンパ球は表皮 内に入り，さらに菌体成分も補体を alternative pathwayを介して活性化しますし，角層自体もそ 机を活性化するため, 乾癬様の病変をとりえま す ${ }^{18)}$.こういう変化はいずれも角層を侵す表在性 真菌症で見られます。白㿏以外には皮膚カンジダ 症でも見られます.Candida albicans の人為的な 接種で，48 時間すると必ず角層下の膿疮がつくら れます。一般にCandida は抢むつ皮膚炎とか，皮 虐と皮膚が合わさる湿った間擦部位でふえて，こ のような膿疮,さらには鱗㞕形成というように炎

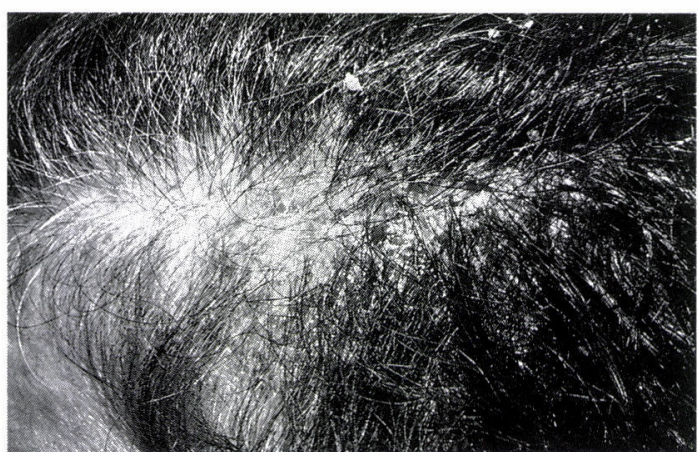

図 15 脂漏性皮膚炎の頭部。いわゆるフケ症 のひどい状態

症を起こしてきます。

要するに, これらの真菌は角層内で繁殖すると 補体の alternative pathway 活性化し，激しい 炎症を生じ，その結果，今度は表皮が増殖をして 菌のいる角層がむけ落ちる，先ほどいいましたよ うに表皮細胞はちょっとした刺激で $\mathrm{TGF} \alpha$ をつ くり出し, その TGF $\alpha$ が表皮の増殖を刺激して, 非常にスピーディーに角化して，いいかげんな機 能しかもたない角層をつくります。それが乾燥し てぼろぼろと皮膚の表面から鱗居というかたちで むけ落ちるので，この菌も一緒に生体から捨てら れてしまいます19)。こういうところにステロイド 外用剂を塗って炎症を抑えると絶対に治らない白 癬や Candida 症をつくることになります。こうい うかびでもう一つ，角層の中には入らなくても， やはり乾癬様の病変をつくるものがあります。そ れはPityrosporum というかびです。これは先生 方全員が皮膚に常在菌でもっておられます。皮膚 の毛穴から皮脂が出るような年歯になると，脂を 好むかびである Pityrosporum が，頭あるいは顔， わきの下，股などにふえてきます。このかびは皮 膚の脂ぎったところにたくさんいて，その菌体成 分が頭あるいは顔の皮䖉から吸収されます。吸収 されるというのは，毛穴の内側の角層は良いバリ ア機能をもっていません。ですから毛穴からは夕 ンパク成分でも少しは入るのです。即に過敏な人 に卵を塗ると，毛穴のところから莖麻疹ができて くることを観察することができますし，毛穴から は短時間にして物質が吸収されます。そういうこ 


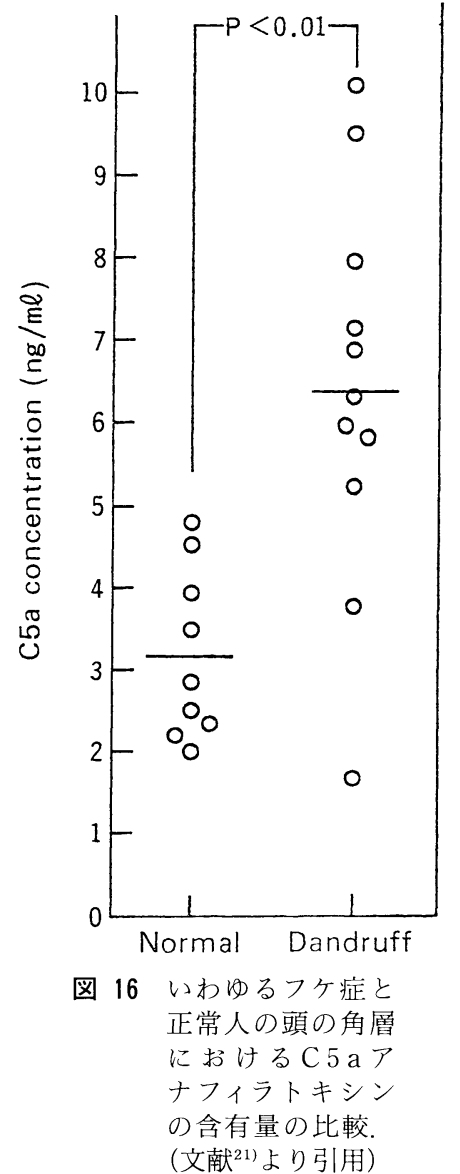

とで顔や頭の皮膚は非常に吸収がいいので，菌体 成分の刺激で，まさに乾癬と同じような鱗屑がで きます。だれでも大人では，たとえば 10 日間ぐら いを頭を洗わないと，フケだらけの頭になります （図 15）。それを私たちは脂漏性皮膚炎と呼んでい ました，顔面，あるいは頭にできます。

こういうフケを顕微鏡で見ると，角層の中に白 血球がいっぱいあるのがわかります。つまり私た ちはフケ，フケとよんでいますが，実はフケは炎 症性の白血球が集まった角層による鱗屑です。組 織的にはこの脂漏性皮膚炎は乾癬と非常に似た白 血球の遊走が見られる病気であるということを， 今から約 30 年前に Pinkus らが報告していま す20). そういうことで, 角層を中心とした真菌症で は，まさに乾癬と同じような病変の病理組織が見 られます。
これは資生堂の研究者たちと今から 10 年ほど 前に報告したものです ${ }^{21}$ 正常人の頭のフケの中に も白血球遊走活性があって C 5 a が認められま す。フケ症だという人たちにはそれがもっと見つ かるというものです(図 16).

結局は白癬, Candida，それからこのような Pityrosporum による脂漏性皮膚炎は，いずれもが 乾癬様というような像をとる疾患です。

\section{まとめ}

今までに申しましたように，実は角層は私たち の皮膚を覆っていながら，からだの外側につくら れ捨てられる異物です。だれもが抗角層抗体とい う抗体をもっています。ただしこの抗体はあまり 病理的学的な変化を起こす働きはありません。

そして角層は私たちの血清と接するとすぐ補体 を活性化して，激しい炎症を起こします。ですか ら外傷とか真菌の感染など角層を中心にして生体 の環境が乱れるようなことがあると，すぐに炎症 が起きて，それが表皮細胞を刺激し，その増殖と 角化過程の促進化をはじめます。そういう角層は 鱗屑としてむけ落ちていって，生体環境を乱すも のを追い払う。ただし，乾㿏のように自己免疫疾 患で，そこには何も微生物がいないけれども角層 下膿疮のできるような病気の場合には，結局この 過程がうまく働かない，というか，どうしょうも ないわけです。一般的にはわれわれにとって非常 に重要な角層はバリアとしての働きをもっていま すけれども，私たちが見る慢性の病気のなかには 角層を中心としたこういう炎症が起こりつづけま す。昔は「らい病」としてこういう人たちは差別を 受けたり，社会生活も送れなかったりといういろ んなつらさを味わうことにもなりました。

いままでのことを簡単にまとめますと，表皮の ケラチノサイトは炎症性刺激を受けると IL-8を 出します。これが非常にたくさんできることに よって炎症により角層が組織液に露出すれば，そ この角層を中心として補体の活性化が起きます。

今日は申しませんでしたが，もちろんこういう 炎症細胞は当然アラキドン酸由来の chemotactic factor も出します。ですから患者さんの鱗屑のな 
かにはたくさんのこういう起炎物質があります。 実際には表皮細胞も脂質由来の起炎物質をつくる ということもいわれていますが, メインは炎症細 胞由来のものと思われます。それから白血球を含 め炎症細胞自体も，IL-8 などを出しますから，ま すます炎症が激しくなって角層下に膿疮がつられ ていきます。

以上が角層を中心とする炎症のお話です。何も 環境条件を乱されなければ私たちの表皮細胞は ゆっくりと角化し 1 力月ぐらいで死骸の角層細胞 になって，それがさらに2 週間して毎日まいにち 1 枚ずつ皮膚の表面から垢としてむけ落ち, 非常 に平和な状態を保つことができるけれども，もし ひとたび，ちょっとでも爪を立ててひっかくだけ でも非常に激しい炎症が起きます。ですから，か ゆいといってひっかくことは，われわれにとって 非常によくないことです。そのようなことで，角 層は私たちにとって非常に大切なバリアであり,

しかも人間は他人を美的な意味でも評価しますの で，その点でも角層は水分を保ってわれわれの皮 膚を美しく見せるという働きもしています。

$$
\text { どうもご静聴ありがとうございました。（拍手） }
$$

(本稿は第 20 回日本炎症学会 [平成 11 年 7 月 $15 \cdot 16$ 日] の会長講演を補足・修正したものである)

\section{文 献}

1) Tagami H, Parrish JA, Ozawa T : SKIN. Interface of a living system. Perspective for skin care system in the future. Elsevier, Amsterdam, 1998.

2）田上八朗：「皮膚の医学. 肌あ饥からトピー性皮膚炎 まで」.中公新書 1467 , 中央公論新社, 1999.

3) Ozawa, Terui T, Tanita M, Kato T, Tagami H : Release of monocyte chemoattractants by polymorphonuclear leukocytes stimulated by their adhesion to stratum corneum opsonized via complement activation, measured with a human acute monocytic leukemia cell line, THP-1. Exp Dermatol $7:$ 151-156, 1998.

4) Terui $T$, Kato $T$, Tagami $H:$ Stratum corneum activation of complement through the antibodyindependent alternative pathway. J Invest Dermatol 92: 593-597, 1989.

5) Terui $T$, Zhen $Y-X$, Kato $T$, Tagami $H$ : Mechanism of human polymorphonuclear leukocyte adhesion to serum-treated corneocytes. J Invest Dermatol 104:297-301, 1995.

6) Tagami H, Aiba S : Psoriasis. (ed. Bos JD), Skin
Immune System (SIS). Cutaneous Immunology and Clinical Immunodermatology. Second Ed, CRC Press, Boca Raton, 1997, p523-530.

7) von den Driesch P : Epidermotropic neutrophilic granulocytes express MAC-1(CD $11 \mathrm{~b} / \mathrm{CD} 18)$ rather than LFA-1(CD $11 \mathrm{a} / \mathrm{CD} 18)$. Arch Dermatol Res 285:444-446, 1993.

8) Tagami H, Iwatsuki K, Takematsu H : Psoriasis and leukocyte chemotaxis. J Invest Dermatol 88: 182s-23s, 1987.

9) Terui $T$, Ishii K, Ozawa M, Tabata N, Kato T, Tagami H : C 3 production of cultured human epidermal keratinocytes is enhanced by INF $\gamma$ and $\mathrm{TNF} \alpha$ through different pathways. J Invest Dermatol 108:62-67, 1997.

10) Takematsu H, Terui T, Ohkohchi K, Tagami H, Suzuki R, Kumagai K : Presence of chemotactic peptides other than $\mathrm{C} 5$ a anaphylatoxin in scales of psoriasis and sterile pustular dermatoses. Acta Derm Venereol(Stockh) 66:93-97, 1986.

11) Schröder JM, Christophers E : Identification of $\mathrm{C} 5 \mathrm{a}$ des arg and an anionic neutrophil-activating peptide(ANAP). J Invest Dermatol $139: 53-58,1986$.

12) Takematsu H, Tagami H : Quantification of chemotactic peptides ( $\mathrm{C} 5$ a anaphylatoxin and IL8) in psoriatic lesional skin. Arch Dermatol 129 : 74-80, 1993.

13) Bergh K, Iversen OJ, Lysvand H : Surprisingly high levels of anaphylatoxin C 5 a des Arg are extractable from psoriatic scales. Arch Dermatol Res $285: 131-134,1993$.

14) Tagami H, Aiba S : Overview of Immunology. (eds. Roenigk HH Jr, Maibach HI), Psoriasis. 3rd Ed. Revised and Expanded, Marcel Dekker, New York, 1998, p191-208.

15) Nickoloff BJ, Kunkel SL, Burdick M, Strieter RM : Severe combined immunodeficiency mouse and human psoriatic skin chimeras. Validation of a new animal model. Am J Pathol $146: 580-588,1995$

16) Tagami $\mathrm{H}:$ Triggering factor. Clinics in Dermatol $15: 677-685,1997$.

17) Horiuchi N, Aiba S, Ozawa H, Sugawara S, Rikiishi H, Kumagai K, Tagami H : Peripheral blood lymphocytes from psoriatic patients are hyporesponsive to $\beta$-streptococcal superantigens. $\mathrm{Br} \mathrm{J}$ Dermatol 138:229-235, 1998.

18) Tagami $H$, Kudoh $K$, Takematsu $H$ : Inflammation and immunity in dermatophytosis. Dermatologica $179: 1 \mathrm{~s}-8 \mathrm{~s}, 1989$.

19) Tagami H, Kudoh K, Tanaka M, Aoyama H, Saijo $\mathrm{S}$ : Biodefense agains cutaneous candidiasis. (eds. Suzuki S, Suzuki M), Fungal cells in biodefense mechanism. Saikon Publishin Co, Tokyo, 1997, p8995.

20) Mehregan AM, Hashimoto K : Pinkus' Guide to Dermtohistopathology. Fifth Ed, Appleton \& Lange, Norwalk, 1991.

21) Kikuchi T, Horii I, Sakamoto T, Nakayama $Y$, Tagami H : Demonstration of neutrophil chemotactic anaphylatoxins in human dandruff. Arch Dermatol Res 281:482-486, 1989. 